\title{
Nieuwe opvattingen over het moderne imperialisme
}

\author{
B. W. SCHAPER
}

Een opdracht, op korte termijn een summary te leveren voor een voordracht, die men over vijf maanden houden moet, grenst aan het onmenselijke. Uiteraard aanvaardt men hem met de nodige reserves en in de illusie, daaraan in die vijf maanden nog wel iets te kunnen doen. Dat 'iets' blijkt dan achteraf vrij weinig, waardoor de 'reserves' bepaald niet zijn verminderd. Het onderwerp behoort trouwens toch reeds tot die verschijnselen, die men moeilijker in zijn greep krijgt, naarmate men zich er langer mee bezig houdt ${ }^{1}$.

Daartoe draagt nog bij, dat de term 'imperialisme' in de loop der jaren zo belast en geladen is geraakt, dat hij nauwelijks voor wetenschappelijk onderzoek en discussie bruikbaar is. Er is veel waars in de klacht van een scherp analyticus en kenner der materie, W. K. Hancock, dat de hele notie 'imperialisme' een pseudoconceptie is, die begint met alles duidelijk te maken, maar eindigt met alles te vertroebelen. Het is volgens hem een 'woord voor analfabeten in de sociale wetenschappen'. Het wordt 'zo arrogant en grillig gebruikt, dat het bepaald een belemmering voor het denken is geworden'. Kortom: 'imperialisme is geen woord voor geleerden. De emotionele echo's die het oproept zijn te heftig en te tegenstrijdig' ${ }^{2}$. Daarin zit veel waars, maar gelukkig ook wel enige overdrijving. Trouwens: ook die verwerping is misschien te emotioneel geladen om geheel uit wetenschappelijke bezorgdheid voort te komen.

Eenzelfde argwaan komt boven, als een ander Brits historicus, G. Kitson Clark, aan het eind van een scherpzinnig essay over 'Imperialism' ${ }^{13}$ de raad geeft, woorden als 'imperialisme', 'kolonialisme', 'exploitatie' en dergelijke maar uit te bannen. Het zijn volgens hem, naar een beeld van John Ruskin, 'masked words', dat wil zeggen 'woorden met een sterke emotionele kracht, maar dubbelzinnige betekenis of überhaupt geen betekenis, waarachter de mensen hun vooroordelen verbergen en

1. Een opgave van recente literatuur heeft weinig zin, aangezien deze in het betoog zelf aan de orde komt. Een uitzondering moge worden gemaakt voor de heldere uiteenzetting van de problematiek door M. E. CHAMBERLAIN, The New Imperialism (Londen: Historical Association, 1970).

2. W. K. HANCOCK, ed., Survey of British Commonwealth Affairs, II, Problems of Economic Policy, 1918-1939, Part i (Londen, 1940) 1-2; w. K. HANCOCK, Wealth of Colonies (Cambridge, 1950) 17.

3. G. KITSON CLARK, An Expanding Society. Britain 1830-1900 (Cambridge, 1967) hoofdst. v, $61 \mathrm{vlg}$. Soortgelijke kritiek bij E. M. WINSLOW, The Pattern of Imperialism. A Study in the Theories of Power (New York, 1948) $60 \mathrm{vlg}$.

4

BMGN 86 afl.l. 
waarmee zij hun vertogen menen te versterken'. Kitson Clark plaatst het woord daarom tussen aanhalingstekens, waarmee hij terugkeert tot de tijd van oorsprong van het woord in de jaren 1870 en volgende ${ }^{4}$.

Ongetwijfeld behoort de term 'imperialisme' tot de meest dubbelzinnige, misbruikte en geperverteerde woorden uit het arsenaal, waaruit de sociale wetenschappen, de geschiedenis incluis, moeten putten, maar dat zij voor een ideologische manipulatie niet kunnen behoeden. Hoezeer 'imperialisme' in het politieke strijdgewoel tot een stereotype, een slogan en een scheldwoord verworden is, bleek uit een onderzoek naar politieke radio-uitzendingen over de hele wereld in de maand februari 1960: in één op tien uitzendingen werden de woorden 'imperialisme' en 'imperialisten' gebruikt en wel in negatieve zin, vaak gecombineerd met epitheta als 'honden' en 'zwijnerijen'.

Ik zal U verder niet vermoeien met de historische semantiek, maar duidelijk is wel dat het woord 'imperialisme' een vitaal woord is, dat in de eeuw van zijn bestaan volgens sommigen twaalf maal van betekenis is veranderd, terwijl anderen niet minder dan zeventien betekenissen onderscheiden ${ }^{6}$. Deze situatie noopt er wel toe ons vooraf er rekenschap van te geven waarover we het hier en nu zullen hebben.

Wat we hier op het oog hebben is een verschijnsel of een verschijnselencomplex, dat een bepaald tijdvak, nl. van ca. 1880 tot 1914, in zo hoge mate heeft gekarakteriseerd, dat men deze periode in de meeste - niet alle - handboeken aanduidt als het 'tijdvak van het moderne of nieuwe imperialisme'. Voor een omschrijving van 'imperialisme' zou ik dan willen afspreken in dit verband te gebruiken de formule, van een historicus, die weet waarover hij het heeft, nl. William Langer, schrijver van het klassieke The Diplomacy of Imperialism, dat de hoofdmoot van de bedoelde jaren, nl. de periode van 1890 tot 1902, gedetailleerd beschrijft. Zij luidt:

simply the rule or control, political or economie, direct or indirect, of one state, nation or people over other similar groups, or perhaps one might better say the disposition, urge or striving to establish such rule or control ${ }^{7}$.

$\mathrm{Nu}$ heeft men terecht opgemerkt dat een zo geconcipieerd expansiestreven van alle tijden is. In de periode 1880-1914 neemt dit streven in Europa echter zulke specifieke trekken, zulk een verhevigde intensiteit en verhoogde doelbewustheid aan, dat

4. Cf. A. P THORNTON, The Imperial Idea and its Enemies. A Study in British Power (Londen, 1959) 30 .

5. R. KOEBNER en H. D. SCHMIDT, Imperialism. The Story and Significance of a Political Word, 1840-1960 (Cambridge, 1964) xviii. Voor de epitheta zie M. PERHAM, Bilanz des Kolonialismus (Stuttgart, 1963) 8 vlg.

6. KOEBNER en SCHMIDT, Imperialism, xiii; over veelheid van betekenissen, WINSLOW, Imperialism, $60 \mathrm{vlg}$. Een aantal definities vindt men in L. L. SNYDER, The Imperialismus Reader (New York, 1962) 19 vlg.

7. W. L. LANGER, The Diplomacy of Imperialism, 1890-1902 (2e dr.; New York, 1951) 67. 


\section{B. W. SCHAPER}

men van een typerend, identificerend verschijnsel kan spreken. Er is mijns inziens bepaald een wezenlijk, kwalitatief verschil tussen de periode van 'informal imperialism' (term ingevoerd door de Engelse historiografen Gallacher en Robinson) in de eerste drie kwart van de negentiende eeuw, en de min of meer overspannen 'scramble' voor koloniale gebieden en invloedssferen in het laatste kwart ${ }^{8}$.

Hoewel de cijfers in verschillende werken uiteenlopen, wijzen de verhoudingsgetallen ook bij voorzichtige auteurs als Fieldhouse duidelijk op een tempoverhoging en omvang-vergroting in het laatste kwart van de negentiende eeuw (de 'scramble for Africa' is ca. 1900 vrijwel voltooid) ${ }^{9}$. Gallacher en Robinson hebben er terecht op attent gemaakt, dat ook vóór 1880 met name door Engeland heel wat steunpunten en invloedssferen, maar ook uitgebreide territoria, met name in India, zijn bezet, en dit geldt eveneens voor Frankrijk in Noord- en West-Afrika en in IndoChina $^{10}$. Maar wat hieraan ontbrak was een welbewuste expansiedrang of expansiepolitiek, geconcipieerd en gecontroleerd door en vanuit het moederland zelf, en in scherp bewuste rivaliteit met andere Europese mogendheden. Meer nog dan het 'informele' karakter, dat het imperialisme vóór 1880 kenmerkte en met de term 'gun boat diplomacy' kernachtig wordt aangeduid, draagt het duidelijk het stempel van de tegenzin van regeringen en een groot deel der openbare mening in het moederland (het zgn. 'reluctant imperialism'). Bovendien is karakteristiek, dat we bovenal in deze vóór-tijd vaak kunnen spreken van een typisch 'periferische' expansie.

Van deze term 'periferisch' tegenover 'Eurocentrisch' wordt in de nieuwere theoretische en historiografische literatuur veel werk gemaakt. Auteurs als Fieldhouse, Hancock, Gallacher en Robinson en hun 'school', en ook de in Amerika werkende auteurs Gann en Duignan ${ }^{11}$, tonen aan dat vaak bepaalde, soms kleine groepen in bestaande koloniale gebieden, ter plaatse op expansie aandrongen en deze ook forceerden. Planters, missionarissen, onderzoekers, avonturiers, wervers van arbeidskrachten enz., die leefden aan onveilige en onstabiele grenzen, poogden die te verschuiven of veiliger te maken, verstoorden inheemse samenlevingen en dwongen achteraf weerspannige regeringen thuis tot actieve interventie. Hancock bouwt hierop een hele 'frontier'-theorie, kennelijk geinspireerd door het bekende Amerikaanse voorbeeld. Hij meent daarmee niet alleen een groot deel van de expansie in

8. J. GALLACHER en R. ROBINSON, 'The Imperialism of Free Trade', Economic Historical Review $\{E H R), 2$ e s., VI, i (1953) 1-15. Een kritiek hierop van O. MACDONAGH, 'The Anti-Imperialism of Free Trade', EHR, 2e s., XIV, ii (1961) 489-501.

9. D. K. FIELDHOUSE, Die Kolonialreiche seit dem 18. Jahrhundert (Frankfort, 1965) 138.

10. GALLACHER en ROBINSON, 'Imperialism', 1-15.

11. D. K. FIELDHOUSE in de inleiding op zijn The Theory of Capitalist Imperialism (Problems and Perspectives in History, Londen, 1967) xiv vlg.; L. H. GANN en P. DUIGNAN, Burden of Empire. An Appraisal of Western Colonialism in Africa, South of the Sahara (New York, 1967). Beide auteurs geven een nieuw verzamelwerk uit in vier delen waarvan deel één in 1969 verscheen, L. H. GANN en P. DUIGNAN, ed., Colonialism in Africa, 1870-1960, I, The History and Politics of Colonialism, 1870-1914 (Cambridge, 1969). 
Afrika, maar eigenlijk het hele koloniale en expansieproces vanaf de late Middeleeuwen te verklaren ${ }^{12}$. Het begrip doet wat gekunsteld aan, als het later gespecificeerd wordt en naast zogenaamde 'settler's' en 'trader's frontiers' ook 'miner's' en 'investor's frontiers' worden geïntroduceerd. Het woord is dan niet meer zo'n 'unpretentious every day-word' als de schrijver blijmoedig meent. Gann en Duignan voegen er bovendien nog allerlei categorieën als 'hunter's, agricultural' of 'farmer's frontiers' en zelfs 'gunpowder frontiers' aan toe - wat de zaak niet eenvoudiger maakt ${ }^{13}$. Men moet evenwel erkennen, dat deze koloniale 'frontiers'-these en het aspect van de 'turbulent frontier' een nuttig correctief vormt op een zuiver Eurocentrische interpretatie van bijvoorbeeld de koloniale geschiedenis van Afrika.

Waarin deze vernieuwers te ver gaan - Fieldhouse overigens slechts ten dele - is in hun besluit om op grond van dergelijke theorieën te ontkennen, dat er een essentieel verschil, een historische caesuur tussen het Vroeg- en Midden-Victoriaans imperialisme enerzijds en het Nieuwe Imperialisme van na 1880 zou bestaan. Gann en Duignan, die onder anderen deze stelling poneren, moeten zelf erkennen, dat 'geen Europese staat vóór 1871 welbewust ('deliberately') op uitgebreide imperiale annexaties gericht was', terwijl zij ook toegeven, dat na 1871 'de vaart der koloniale expansie zich in Afrika versnelde'. Wat ook moeilijk te loochenen is, als men weet, dat in 1870 ruwweg één tiende van het Afrikaanse continent onder Europese controle stond en in 1900 ruwweg één tiende daarbuiten gebleven was ${ }^{14}$. Men kan dan ook mijns inziens zeer wel de periode 1880-1914 (eventueel tot 1920 te verlengen met het oog op de verwervingen in de Eerste Wereldoorlog) handhaven als climax in imperialistische expansie vooral vanuit Europa. Daarbij is in deze diachronische beschouwingswijze wel met een faze-verschil in verschijningsvormen rekening te houden, gepaard gaande met geografische verschuivingen.

$\mathrm{Na}$ de faze van het voornamelijk informele imperialisme van Engeland en het sterk militair geïnspireerde expansionisme van Frankrijk uit de periode van 1815 tot 1870 of 1880, volgt de periode van 1880 tot 1914 (of 1920) als die van het moderne imperialisme bij uitstek, waaraan behalve Engeland en Frankrijk, ook Duitsland, Italië, Rusland, Japan en de Verenigde Staten - niet te vergeten ook 'Einzelganger' als Koning Leopold II van België - deelnemen, met achtereenvolgens Afrika, China, de Pacific en het Nabije Oosten als actiecentra. Dit overwegend Europese imperialisme is in 1920 over zijn hoogtepunt heen. Het Amerikaanse - lang en overwegend 'informal' - zet dan door, evenals het Japanse, terwijl het Russische zich in een nieuwe gedaante, als een soort 'sociaal imperialisme' aan het eind van het Interbellum manifesteert. Dit draagt dan, evenals het Duitse en Italiaanse van die periode, een sterk ideologisch karakter. De periode 1880-1914 blijft dus voor

12. HANCOCK, ed., Survey, 4 vlg.

13. GANN en DUIGNAN, ed., Colonialism, I, 122.

14. Ibidem, 5 vlg. Cf. M. E. CHAMBERLAIN, Imperialism, 24. 
ons die van het moderne imperialisme bij uitstek, mede zoals de Duitse historicus H.-U. Wehler terecht betoogt, omdat ook de tijdgenoten een typisch fenomeen van de laatste dertig jaren der negentiende eeuw nadrukkelijk zo hebben aangeduid, zij het na enige aarzeling ${ }^{15}$.

H. Gollwitzer voert in zijn Europe in the Age of Imperialism, 1880-1914 (Londen, 1969) een dwingender argument voor zijn eigen typering aan door erop te wijzen dat in die periode - zij het met tempo- en accentverschillen - alle betrokken regeringen aan imperiale consolidatie of expansie een centrale plaats in hun regeringsprogram toekenden. Daarbij identificeerden zich leidende groepen met imperiale opvattingen en programma's, maakten zich van de publieke opinie meester en gaven aanleiding tot imperiale ideologieën en organisaties. Bovendien manifesteerden zich wijzigingen en verschuivingen in de binnenlands-politieke en sociale verhoudingen, die in een imperiale politiek hun weerslag en uitlaat vonden. 'De stijl van het tijdperk werd door de wisselwerking van al deze factoren bepaald', aldus Gollwitzer ${ }^{16}$.

Het wil mij voorkomen, dat het Nederlandse imperialisme, zowel naar fasering als naar karakter tot dit Europese moderne imperialisme behoort, zij het met die aarzeling, aan de Nederlandse neutraliteitspolitiek verbonden, die het Nederlandse imperialisme tot een typische vorm van 'reluctant imperialism' stempelt met voorkeur voor een informeel karakter - een aarzeling, die pas eind negentiende en begin twintigste eeuw in Nederland zelf, in de tijd der 'ethische politiek', overwonnen schijnt te worden.

Naast deze diachronische bepaling wordt in de moderne literatuur evenzeer gediscussieerd over de typering, verklaring en waardering van het verschijnsel. Wat de waardering betreft zijn de 'ups' en 'downs' daarin vaak onvoorspelbaar. Terwijl in de politieke polemiek de negatieve beoordeling sterk overheerst, constateert men in de jongste vakliteratuur duidelijk ook een positiever tendentie, die wellicht een reactie is op de dekolonisatie en haar nasleep.

Typering en verklaring zijn voor ons historici mijns inziens het interessantst. Lange tijd is daarbij ten aanzien van het moderne Europese imperialisme de nadruk gelegd op het economisch aspect, zowel bij de karakteristiek als bij de interpretatie. Die twee benaderingen behoeven allerminst samen te vallen. Terecht heeft David A. Landes op het verschil gewezen tussen economisch imperialisme en een, meestal monocausaal bedoelde economische interpretatie van het imperialisme ${ }^{17}$. Het eer-

15. H.-U. WEHLER, Bismarck und der Imperialismus (Keulen-Berlijn, 1969) 24. In 1878 klaagde Lord Camarvon nog, dat de Britse constitutie niets van 'imperialisme' afwist, een 'newly coined word'. Cf. KOEBNER en SCHMTDT, Imperialism, 153.

16. H. GOLLWITZER, Europe in the Age of Imperialism 1880-1914 (Londen, 1969) 15-16.

17. D. A. LANDES, 'Some Thoughts on the Nature of Economie Imperialism', Journal of Economic History \{JEH) XXI (1961) 496. 
ste definieerde hij als 'de vestiging of exploitatie van overheersing van de ene groep over de andere met het oog op voortgezet materieel voordeel', waarbij echter ook andere motieven een rol kunnen spelen, terwijl dit economisch imperialisme vaak in 'informele' vormen optreedt. Landes is in dit opzicht in zijn opvatting omtrent de verschijningsvormen van imperialisme ruimer en gevarieerder dan William Langer, die in een zuiver theoretische uiteenzetting (voor historici vaak een wat hachelijke onderneming!) zich ertegen verzette de interventie van kooplieden en bankiers in de zaken van andere landen met 'imperialisme' aan te duiden. 'Als U imperialisme wilt scheiden van territoriale controle blijft U nergens', was een van zijn uitspraken. Als men van financieel imperialisme en dergelijke spreekt, moet men ook spreken van cultureel imperialisme en religieus imperialisme 'and what not?'. Volgens Langer komt men dan tot een onmeetbare en onhanteerbare conceptie $^{18}$.

Die handschoen, nl. de woorden 'what not', is opgenomen door de intelligente analyticus A. P. Thornton, die in zijn Doctrines oflmperialism juist op de diversiteit in de vormen van overheersing, politieke, economische, culturele, psychologische etc. de nadruk legt ${ }^{19}$. Deze 'pluralistische make-up' van het imperialisme (Gollwitzer) wordt tegenwoordig vrij algemeen aanvaard. Naast machtspolitieke en tactischdiplomatieke worden sociale, economische, culturele en ideologische aspecten als even belangrijk erkend. Aan deze veelheid van aspecten beantwoordt een even grote verscheidenheid van factoren, die tot imperialisme leiden: prestigezucht, missiebesef, nationale en rassen-vooroordelen, elitair en paternalistisch optreden maar ook sociaal darwinisme en andere ideologieën. Deze psychologische en ideologische factoren hebben evenzeer een aandeel als de vermeende behoefte aan vlootstations en andere strategische punten, de wens om op toekomstmogelijkheden ber slag te leggen of de wil om over grondstoffen en markten voor goederen en kapitalen te beschikken. En niet te vergeten ook de zorg voor veilige vestiging van eigen onderdanen. U ziet: een hele staalkaart.

Het is uiterst moeilijk, de relatieve invloed van elk dezer aspecten en drijfveren van geval tot geval te meten. Daartoe draagt bij dat geen van alle geïsoleerd in zijn werkingskracht te bepalen valt; zij zijn daartoe al te zeer in één grote samenhang, een levend complex verweven. Een dergelijke complexiteit behoeft echter principieel de hypothese van een in laatste instantie beslissende factor niet uit te sluiten, evenmin als omgekeerd de vooropstelling daarvan met die complexiteit in strijd behoeft te zijn.

Zo heeft bijvoorbeeld Lenin de complexiteit van het imperialisme en het daardoor

18. W. L. LANGER, 'A Critique oflmperialism', Foreign Affairs, XTV (1953) 102-115. Het artikel is eveneens verschenen in H. M. WRIGHT, ed., The 'New Imperialism'. An Analysis of Late Nineteenth-Century Expansion (Problems in European Civilization, Boston, 1965) 68-76.

19. A. 'P. THORNTON, Doctrines of Imperialism (New York, 1965) 5, daarin ook citaat van Langer. 
getypeerde tijdperk uitdrukkelijk erkend. Uit zijn gepubliceerde Notitieboeken bleek, dat hij niet over één nacht ijs ging en voor zijn bekende werk over Het Imperialisme als hoogste stadium van het Kapitalisme (1916) 148 boeken en 232 artikelen had doorgewerkt ${ }^{20}$. De drang naar koloniën was volgens Lenin slechts één aspect van de ontwikkeling van het kapitalisme in dit tijdperk en misschien niet eens het beslissende. Imperialisme was een proteus-achtige conceptie, waar men niet één aspect, bijvoorbeeld de drang naar koloniën, zo maar mocht uitlichten en dit tot alomvattend verklaren. Lenin streefde, naar Kemp ons vertelt, niet naar een 'overall definition', maar naar een definitie, waarin het onderscheidende karakter van het moderne imperialisme in zijn relatie tot het monopolie-kapitalisme duidelijk naar voren trad. Op de keper beschouwd zijn het bij Lenin overigens meer de spanningen tengevolge van tempo-verschillen in de nationale ontwikkelingen, die tot de rivaliteiten en uiteindelijk tot oorlogen voeren, dan de interne wetmatigheden van de kapitalistische ontwikkeling zelf, al moesten die volgens de leer door hun interne contradicties tot een explosieve ondergang van het kapitalisme leiden.

Het heeft geen zin hier nog eens de historische onhoudbaarheid van de economische interpretatie van het imperialisme in monocausale en wetmatige zin in de brede uiteen te zetten, of men nu de Hilferdings-Leninse these van het monopolie-kapitalisme of 'Finanzkapital', dan wel de theorie van Rosa Luxemburg inzake de dwang tot accumulatie via een niet-kapitalistische omgeving als uitgangspunt neemt. De laatste is ten onzent enige jaren geleden nog eens weer door Daalder weerlegd ${ }^{21}$.

Er verschijnen echter nog altijd als Marxistisch aangeduide werken op dit gebied. Zo werd het in 1967 verschenen werk van T. Kemp uitdrukkelijk als Marxistisch aangekondigd. Kemp onderwerpt de verschillende Marxistische theorieën, ook die in de Sowjet-Russische sfeer, evenals hun bestrijding aan een vaak scherpzinnige analyse. Aan een eigen door hem noodzakelijk geachte nieuwe Marxistisch-Leninistische theorie komt hij evenwel niet toe en bovendien neemt hij bij voorbaat aan, dat zij door de tegenstanders, die alleen maar contradogma's zouden aandragen, toch niet aanvaard zou worden. Hetgeen hem overigens niet belet allerlei reeds lang

20. Cf. T. KEMP, Theories of Imperialism (Londen, 1967) 64. Kemp ontleent zijn gegevens aan een studie van L. G. CHURCHWARD, 'Towards the Understanding of Lenin's Imperialism', The Australian Journal of Politics and History, V (1959). Het hierna volgende over Lenin is ten dele aan hem ontleend.

21. H. DAALDER, 'Capitalism and the Underdeveloped Areas. The Political Economy of (Anti-) Imperialism' in: E. DE VRIES, ed., Essays on Unbalanced Growth (Institute of Social Studies, grote Serie, X, 's-Gravenhage, 1962) 133-165. Voor verdere literatuur inzake de Marxistisch-Leninistische theorieën over imperialisme o.a. FIELDHOUSE, Imperialism, zie noot 11; J FREYMOND, Lénine et l'imperialisme (Lausanne, 1951); W. B. H. COURT, 'The Communist Doctrines of Empire' in Appendix op: HANCOCK, ed., Survey, 294-305. 
overleefde stokpaardjes, zoals de wet van de afnemende winstvoet, bij verschillende gelegenheden te laten opdraven ${ }^{22}$.

Pretentieuzer, maar even onbevredigend lijkt mij het 'Marxistische' stempel, dat de Duitse onderzoeker H.-U. Wehler op zijn Bismarck und der Imperialismus heeft aangebracht. Wehler werkt mijns inziens met een veel te wijd en daardoor te vaag, als fundamenteel opgevat, alle verhoudingen revolutionerend industrialisatie-proces. De structurele en conjuncturele ontwikkelingen daarin moeten de sleutel leveren voor de nationaal- en internationaal-politieke verschijnselen. Maar de relatie tussen theorie en praktijk, in casu de Duitse koloniale politiek in de jaren tachtig, doet nogal geforceerd aan, waarbij de selectie der verschijnselen duidelijk onder invloed van de vooraf opgestelde theorie staat. Vruchtbaarder lijken mij dan ook de conclusies, waartoe vorig jaar het 28ste Congres van Duitse historici te Keulen kwam en waarbij, na een discussie waaraan ook de genoemde Wehler een grote bijdrage leverde, drie hoofdtypen van het moderne imperialisme werden onderscheiden:

1. een 'informeel imperialisme', d.w.z. een indirecte heerschappij, bijvoorbeeld in economische zin, over een bepaald gebied;

2. formele expansie, na annexatie of uitroeping van een protectoraat;

3. een 'sociaal imperialisme', met koppeling van een expansieve buitenlandse politiek aan sociale hervormingen, om aan verdergaande eisen tot democratisering te ontkomen $^{23}$.

Maar hierbij is van een door de innerlijke wetmatigheden van het kapitalisme bepaalde ontwikkelingsgang naar het imperialisme in authentiek Marxistische zin geen sprake.

Bekend is trouwens, dat ook de grote origmator van de economische interpretatie, J. A. Hobson, geen onontkoombaar, dwangmatig proces aannam en bovendien alle aandacht ook aan andere aspecten schonk. Misschien heeft zijn aanklacht tegen 'power, pride, prestige' en 'pugnacity', tegen 'predatory economics' en 'parasites upon patriotism' dankzij de alliteratie-werking groter invloed gehad dan zijn onder-consumptietheorie, die hij in een latere editie bovendien nog corrigeerde. In wezen staat Hobson, die in het imperialisme eigenlijk een irrationele uitwas van het kapitalisme zag, wellicht dichter bij denkers als Schumpeter met zijn atavismetheorie of bij Thorstein Veblen, voor wie imperialisme een vorm van 'conspicuous

22. KEMP, Imperialism, 163. Terwijl Kemp het toch op Lenin houdt, is door principiële tegenstanders als Gann en Duignan onverwacht Lenins zo fel bestreden tegenstander Kautsky herontdekt en, vanwege positiever waarderingen van de kapitalistische ontwikkeling, ten troon verheven! Zie GANN en DUIGNAN, Burden of Empire, 50 vlg; GANN en DUIGNAN, ed., Colonialism, iii vlg.

23. Ik dank deze informatie aan mijn Leidse medewerkers J. F. Jacobs en H. B. Schot. 
consumption' betekende, dan bij de strikt economisch redenerende Marxistische theoretici ${ }^{24}$.

Natuurlijk heeft het materiële belang, ook in oudere vormen van imperialisme, vaak geprevaleerd. Dat dit materiële belang in onze periode vaak door de voorvechters zoals Leroy Beaulieu, Jules Ferry en anderen werd geafficheerd, heeft de theoretici wellicht soms misleid, maar het is ook een bewijs voor de zwaarwegendheid van het economisch argument in die tijd. Van een homogene 'kapitalistische bourgeoisie' of een 'coherent businessclass' kan men althans in dit verband niet spreken. Juist de spanningen tussen verschillende sociale en economische groeperingen en hun politieke uitwerking zijn werkzame factoren geweest en terecht werd dan ook op de functie, die het imperialisme in de binnenlandse machtsconstellatie vervult, op het Keulse Congres een zwaar accent gelegd.

Uiteraard heeft de groeiende interpenetratie van het politieke en sociaal-economische leven - de bekende vervlechting van staat en maatschappij - ook op het gebied van de buitenlandse politiek tot een cumulatie van energieën op nationale schaal geleid, die het potentieel van de expansiedrang kon versterken. In combinatie met een sociaal reformisme lag hier ook de mogelijkheid van een 'sociaal imperialisme', waardoor zowel in Engeland als in Duitsland leidende groepen, zoals een deel der Fabians, de Webbs voorop, werden gegrepen, maar dat de bredere lagen der moderne arbeidersbeweging toch veel minder aantastte. Daarnaast werd ook met grover geschut gewerkt en op de massa-instincten in nationalistische zin gemikt, waarbij de nieuwe communicatiemiddelen, zoals de goedkope massa-pers, een grote rol speelden. Men concludere daaruit echter niet te lichtvaardig tot een nauwe relatie tussen democratie en imperialisme. Het échec van Chamberlain's 'squalid argument' en van het brood- en werk-imperialisme van de Tariff Reform League vormt daartegen een waarschuwing. Zoals ook het geringe succes van de pogingen in de groep rondom Friedrich Naumann in Duitsland, die de massa's onder de leus van democratie en imperium wilde vangen ${ }^{25}$.

Aan de groeiende drang naar machtsbevestiging en machtsuitbreiding die zich in het laatste kwart van de negentiende eeuw openbaart, hebben technologische ontwikkelingen stellig het hunne bijgedragen. Nieuwe militaire technieken als het machinegeweer en licht veldgeschut, nieuwe verkeersontwikkelingen als spoorweg- en

24. Cf. R. J. HAMMOND, 'Economie Imperialism. Sidelights on a Stereotype', JEH, XXI (1961) 598; THORNTON, Doctrines, 55-56. Met Veblens 'conspicuous waste' zou trouwens Rosa Luxemburgs probleem van de realisering der oorspronkelijke accumulatie tevens van de baan kunnen zijn.

25. GOLLWITZER wijdt in Imperialism aan dit thema, dat stellig een diepergaand onderzoek vereist, twee hoofdstukken, 'Imperium and Libertas' en 'Social Imperialism'. Cf. ook het bekende werk van B. SEMMEL, Imperialism and Social Reform. English Social Imperial Thought, 1859-1914 (Londen, 1960). 
kanaalaanleg, nieuwe communicatiemogelijkheden van allerlei slag verhoogden de technologische superioriteit van de Westerse wereld. Die superioriteit vormt ook de achtergrond van allerlei geestelijke motiveringen, zoals prestige, cultureel missiebesef, roeping tot 'ontsluiting' en 'opheffing'. Hierdoor kan juist ook een 'ethische' politiek tot een bijzonder zelfbewuste vorm van imperialisme worden, zoals aan ons Calvinistisch volksdeel en zijn leiders wel was toevertrouwd.

Deze factor van de 'disparity of power', zoals David Landes hem noemde, speelde uiteraard in de vroege, 'periferische' expansie, bij de 'frontier'-verschijnselen, van allerlei min of meer autonoom optredende groepen uitgaande, een bijzondere rol. Hilaire Belloc's 'We have the Maxim gun and they have not ${ }^{26}$ is de kortste verklaring voor de koloniale successen van de Stanleys, de Brazzas, de Van Heutzen $e$ tutti quanti. Er konden zich nog betrekkelijk lang zulke lokale initiatieven laten gelden. Zelfs deden zich op groter of kleiner schaal allerlei 'sub-imperialismen' voor niet alleen in de vorm van de Chartered Companies, maar ook in het optreden van Westafrikaanse negerstaten. Verwant hieraan zijn de curieuze plannen voor een 'imperial partnership', kort vóór 1914 in India gekoesterd door voormannen van het Indische nationalisme, met het oog op deelneming in een koloniale onderneming in Oost-Afrika ${ }^{27}$.

In de grote 'Scramble for Africa', in het gedrang aan de toegangspoorten van China rond 1900, in de jacht op servituten en eilandengroepen in de Stille Zuidzee, en in het warnet van olie- en spoorwegintriges in het Nabije Oosten, zijn het de grote mogendheden zelf die welbewust, zij het niet altijd openlijk, de operaties bepalen. Zij zijn het die hun machtsverhoudingen en -aspiraties, in Europa zelf vastgelopen, op de buitenwereld projecteren en op meer of minder 'vreedzame' wijze regelen, maar altijd ten koste van de onderontwikkelde gebieden, wier machteloosheid een vacuüm betekende, dat opvulling vereiste: want 'power, like nature - zo herinnert ons Landes - always abhors a vacuüm'. Hier zijn we bij het specifieke operatieterrein van de 'diplomacy of imperialism', die de hele periode van ca. 1880 tot 1914 beheerste.

Het lijkt me vrij onvruchtbaar voor deze, ook door de tijdgenoten - een Salisbury incluis - opgemerkte explosie van imperialistische activiteit één, in laatste instantie beslissende factor of één alles verklarend moment te zoeken. Gallacher en Robinson hebben hun these dat, althans wat de Britten betreft, de hele Scramble for Africa als een 'corollary', een uitvloeisel van de Britse zorg om India en de voorposten daar-

26. Aangehaald bij CHAMBERLAIN, Imperialism, 39.

27. H. LÜTHY in een paper voor het XIIIe Internationale Congres van Historische Wetenschappen, Note on a Problem of British Indian History. The Question of 'Imperial Partnership' during and after the First World War (Moskou, 1970) 4 pp. Het moderne imperialisme nam in het program van dit Moskouse congres geen aparte plaats in en dat nog wel in het gedenkjaar van Lenin! 
van in Egypte en aan de Kaap moet worden gezien, al te zeer toegespitst ${ }^{28}$. Critici als Jean Stengers uit Brussel en andere experts inzake de Sub-Sahara-ontwikkelingen, hebben de primaire en niet enkel afgeleide belangstelling van, naast Fransen en Belgen, ook Engelsen voor West-Af'rika en Congo aangetoond ${ }^{29}$. Indien de verdienste van Gallacher en Robinson was dat zij de aandacht van vaak theoretisch interessante bespiegelingen over de agentia van het imperialisme naar de beslissende instanties in het diplomatieke bedrijf, de 'official mind' met zijn eigen tradities, terugvoerden, dan is het nadeel van hun opvattingswijze toch ook dat zij de diplomatieke geschiedbeoefening weer brachten in het te enge gareel van de actenstudie. Het is mede daarom jammer, dat het desbetreffende onderdeel in het elfde deel van de New Cambridge Modern History en het derde deel van de Cambridge History of the British Empire grotendeels in hun geest is uitgevoerd.

A. J. P. Taylors poging alles terug te voeren tot de virtuose diplomatieke techniek van Bismarck, wordt mijns inziens in betekenis overschat. Volgens hem zou de hele koloniale politiek van Bismarck in de jaren tachtig niets anders zijn dan een nevenproduct van een mislukte Frans-Duitse entente ${ }^{30}$. Maar het Franse imperialisme had in die tijd teveel élan en vaart uit zichzelf om zich louter door Bismarcks diplomatie te laten manipuleren. En van Bismarck zelf kan men aantonen, dat ook deze Realpolitiker tijdelijk gezwicht is voor de koloniale hysterie, in de vorm van de 'Torschluss-panik', de vrees, de deur straks gesloten te vinden; al heeft hij daarover later, maar dat was pas in 1889 , spijt betuigd ${ }^{31}$.

Ook zulke hecht in de traditionele diplomatie gewortelde figuren als Salisbury waren niet altijd immuun voor de nieuwe, op economische mogelijkheden georiënteerde koloniale argumentatie ${ }^{32}$ en ook hij moet onder de indruk zijn gekomen van het door hem zelf geconstateerde feit dat in 1885, bij zijn terugkeer op het Foreign Office, geheel Europa in enkele jaren verstrikt bleek geraakt in ruzies om de verdeling van Afrika ${ }^{33}$. Al was hij bepaald verbijsterd over de koloniale grootheidswaan en bezetenheid waarvan de Belgische koning Leopold TI tegenover hem blijk gaf. Maar diens 'persoonlijk imperialisme' is dan ook een hoofdstuk apart. In Congo

28. Dit is een der hoofdstellingen van j. GALLACHER en R. ROBINSON, Africa and the Victorians.

The Official Mind of Imperialism (Londen-New York, 1961).

29. Cf. J. STENGERS, 'L'Impérialisme colonial de la fin du X1Xème siècle. Mythe ou réalité?', Journal of African History, III, iii (1962) 469-491; c. w. NEWBURY, 'Victorians, Republicans and the Partition of West Africa', ibidem, 493-501. Ook Fieldhouse is op dit punt, bij alle sympathie, kritisch ingesteld. Zie D. K. FTELDHOUSE, EHR, 2e s, XIV, ii (1961) 574-576.

30. A. J. P. TAYLOR, Germany's First Bidfor Colonies 1883-1885 (Londen, 1938), geciteerd bij CHAMBERLAIN, Imperialism, 31-32.

31. Ibidem. Chamberlain steunt op H. A. Turner Jr., 'Bismarck's Imperialist Venture. AntiBritish in Origin?' in: p. GIFFORD en w. R. LOUIS, ed., Britain and Germany in Africa (Yale, 1967). 32. Rede van Salisbury op 14 februari 1895. Cf. G. BENNETT, ed., The Concept of Empire: Burke to Atlee 1774-1947 (Londen, 1953) 312.

33. Salisbury in 1891. Cf. STENGERS, 'Imperialisme', 471. 
was, volgens Stengers, naar het getuigenis van Stanley, een 'enormous voracity', een territoriale vraatzucht het alles beheersend motief. 'lts sole principles were those of greed ${ }^{34}$.

Er zijn, naast de reeds genoemde, nog een reeks factoren werkzaam geweest, die op langer of korter termijn tot de imperialistische explosie van de jaren tachtig hebben bijgedragen. Voorzover economisch zijn deze meer aan specifieke, concrete situaties en constellaties gebonden dan aan algemeen-economische wetmatigheden zoals een overigens natuurlijk niet te loochenen kapitalistische, op economische groei gerichte dynamiek. Zo zijn stellig het verlies van Engelands voorsprong en de neiging tot protectie in Duitsland en Frankrijk, mede onder invloed van conjuncturele en structurele crisis-verschijnselen in de jaren zeventig belangrijke, het chronologisch verloop bepalende gegevens.

Daarnaast zijn er allerlei geestelijke en politieke tendenties zoals een algemeen Europees superioriteitsbesef; al of niet vervulde nationale aspiraties na 1870; vrees voor en afleiding van democratische of revolutionaire strevingen of dreigingen, evenals pogingen om binnenlandse politieke constellaties door buitenlandse machinaties te beheersen. Deze binnen het Europese bestel vaak vastgelopen dynamische krachten vonden een dankbaar operatieterrein in buiten-Europese gebieden, die hunnerzijds aanknopingspunten boden in veelal lokaal beperkte, 'periferische'processen. Kortom, talloze factoren, uit verschillende centra en allerlei sferen in en buiten Europa afkomstig, kwamen in het begin van de jaren tachtig samen om door hun convergentie en cumulatieve werking een bijzondere energie en vaart te verlenen aan de dynamiek en expansiedrang, die de Westerse wereld in de periode der Nieuwe Geschiedenis, door K. M. Panikkar zo treffend het 'Vasco da Gamatijdperk' genoemd $^{35}$, traditioneel hadden gekenmerkt. Terecht zeggen Gann en Duignan dan ook, dat de geschiedenis van het moderne imperialisme alleen in zulk een pluralistische en polycentrische zin kan worden geschreven ${ }^{36}$.

34. J. STENGERS, 'The Congo Free State and the Belgian Congo before 1914', in: GANN en DUIGNAN, ed., Colonialism, I, 274.

35. K. M PANIKKAR, Asia and the Western Dominance. A Survey of the Vasco da Gama Epoch of Asian History, 1498-1945 (Londen, 1953).

36. GANN en DUIGNAN, ed., Colonialism, I, 126-128. De convergentie van een aantal krachten en trends in een bepaald tijdstip lijkt mij een typisch historische categorie, waarmee bepaalde verschijnselen in hun tijdelijke bepaaldheid kunnen worden gekarakteriseerd. Zo schijnt een soortgelijke convergentie verhelderend te werken bij de historische interpretatie van de Industriële Revolutie. Cf. W. M. FLINN, Origins of the Industrial Revolution (Problems and Perspectives in History; 3e dr.; Londen, 1963) 103. Natuurlijk kan men, zoals prof. Th. van Tijn in de discussie in Utrecht aanvoerde, verder naar een 'laatste oorzaak' zoeken, maar hoe lang blijft men dan nog op het terrein der historische wetenschap? Een andere vraag is, of men bij zulk een convergentie van factoren en elementen niet verschillen in gewicht moet pogen vast te stellen. Ik zou dan wel willen erkennen, dat de economische factor waarschijnlijk de zwaarst wegende is geweest in de ontwikkeling van het moderne imperialisme, maar dan minder bij de initiatieven, in eerste aanleg, dan bij de voortzetting, op langer termijn. 
Ook al wist de 'diplomacy of imperialism' de uit dit complexe geheel voortkomende spanningen en botsingen vaak 'vreedzaam' te regelen, meestal werden in dit psychologisch, ideologische en publicistisch 'opgewerkte' bedrijf de internationale tegenstellingen verder geladen en opgevoerd. De prikkeling, de excitatie van nationalistische sentimenten en agressieve instincten vormde eigenlijk de voornaamste bijdrage van het Moderne Imperialisme tot de Eerste Wereldoorlog.

Maar die werkingen van het imperialisme drongen dieper in het nationale leven door en ook tot lang na die Eerste Wereldoorlog. Het hele koloniale en imperiale bedrijf versterkte militaire en autoritaire tendenties in het moederland. Niet alleen in Duitsland, maar evenzeer in Frankrijk en Engeland is een hele koloniaal-geinspireerde literatuur - meestal van de tweede rang, maar daarom niet minder verbreid - in die richting werkzaam. Er is in diverse imperialistische landen een sociaal conglomeraat aanwijsbaar, waarin nog los van allerlei onaangepaste, op avontuur en 'escape' gerichte elementen, een soort nieuwe elite van autoritaire persoonlijkheden met hen omringende clientèles als een nieuw soort feodale volgelingschap verschijnt. In Engeland is dat de uit Zuid-Afrika meegekomen 'Kindergarten' van Alfred Milner; voorts de protégés en later de 'boursiers' van Cecil Rhodes en de Middle East-kliek van Curzon, Cromer en consorten; in Frankrijk onder anderen de bewonderaars van Lyautey. Hun invloed op de nationale samenleving - in Engeland mede via de door hen bewerkte public schools - had een autoritaire, anti-democratische inslag. Terecht heeft Thornton opgemerkt, dat imperialisme als regering van het ene volk over het andere essentieel in strijd is met de democratische conceptie van regering van het volk door het volk ${ }^{37}$. Reeds Hobson vreesde de vorming van een parasitaire eliteheerschappij in Engeland als gevolg van het imperialisme. Ongetwijfeld hebben de na-oorlogse totalitaire stromingen in Europa een vruchtbare voedingsbodem gevonden in de koloniale samenlevingen en de daar heersende ideeënsfeer: in deze relatie tussen totalitarisme en imperialisme heeft Hannah Arendt zeker niet misgetast ${ }^{38}$ De Nederlands-Indische samenleving van vóór 1940 vormde hierop geen uitzondering.

Tenslotte zou ik een poging tot een summiere evaluatie willen wagen. Beoordeling van het verleden in morele termen is altijd hachelijk. Men moet zorgvuldig eigen normen tegenover de algemeen geldende maatstaven van de tijd die men beoordeelt, afwegen, zonder in een karakterloos relativisme te vervallen. In het onderhavige geval waar velen onmiddellijk met een moreel oordeel klaar staan, is die waarschuwing extra op haar plaats, te meer waar de materie bijzonder gecompliceerd is.

Naar de persoonlijke kant gezien heeft men met een hele skala van handelende personen, hun motieven en gedragingen te maken, van wilde avonturiers en door

37. THORNTON, Imperial Idea, 265.

38. H. ARENDT, Origins of TotalitaHanism, II, Imperialism (2e dr.; New York, 1958). 
machtswil bezetenen, zoals Leopold II of Cecil Rhodes, tot paternalistische proconsuls als Lugard die zijn ambt vooral in later tijd als een 'trusteeship' opvatte, of zendelingen en artsen die zich persoonlijk opofferden zoals een Livingstone of Francois Coillard, of in dichterbij gelegen tijd een Albert Schweitzer die overigens uit puur paternalisme zich niet met de dekolonisatie kon verzoenen en dus toch typisch tot de imperialistische sfeer behoort. Een nader onderzoek naar de herkomst en eigenaardigheden van koloniale en imperiale pioniers is stellig interessant, bijvoorbeeld ook vanuit een Freudiaans gezichtspunt. Het valt in het algemeen in elk geval wel te betwijfelen of de Westerse landen altijd het advies hebben opgevolgd van Rudyard Kipling: 'Send forth the best ye breed ...'.

Een beoordeling naar objectieve maatstaven, zowel in zuiver materiële zin als naar beschavingsinvloed, is al niet eenvoudiger. Opvallend is wel dat de meeste economische deskundigen op grond van zorgvuldige berekeningen de exploitatie vooral van de typisch tropische koloniën en dan in het bijzonder de Afrikaanse, althans in onze periode, slechts een zeer partieel succes achten, namelijk slechts voor enkele groepen maar niet voor de gehele economie van het koloniserende land. De 'Balance Sheets of Imperialism' van Grover Clark (1936) vallen in het algemeen negatief uit; de kosten waren gezien de baten onevenredig hoog. Een financieel expert als Cairncross komt inzake de Britse buitenlandse investeringen in het algemeen tot een gunstiger resultaat maar niet duidelijk is welke rol daarbij de typisch koloniale gebieden, los van India en de Dominions, spelen ${ }^{39}$. Merkwaardig is dat Cairncross een verhoging van de rentevoet als een gunstig resultaat aanwijst, hoewel deze de werkgelegenheid en ook het aandeel van de arbeiders in de nationale economie zou kunnen bedreigen. Een Nederlands onderzoek in de jaren 1930 van Tinbergen en Derksen concludeerde juist, als mijn geheugen mij niet bedriegt, tot een lager rentepeil tengevolge van de exploitatie van Nederlands Indië voor de Nederlandse economie, wat als een gunstige factor beschouwd werd ${ }^{40}$.

39. A. K. CAIRNCROSS, Home and Foreign Investment, 1870-1913 (Cambridge, 1953). Geciteerd in FIELDHOUSE, Imperialism, 154-159.

40. Het geheugen is, vooral op langere termijn, altijd een riskante bron. De heren J. B. D. DERKSEN en J. TINBERGEN, voor wier welwillende reactie op mijn verzoek om informatie ik zeer erkentelijk ben, meenden niet mijn opvatting te kunnen bevestigen. Ook in hun bekende 'Berekeningen over de economische betekenis van Nederlands-Indië voor Nederland,' in 1945 in het Maandschrift van het Centraal Bureau voor de Statistiek verschenen, maar gebaseerd op voor-oorlogse gegevens, vond ik geen bevestiging van mijn stelling. Wel bleek daaruit, dat omstreeks 1938 een betrekkelijk hoog percentage van het nationaal inkomen, nl. 14 procent, primaire en secundaire gevolgen samengenomen, uit Ned. Indië afkomstig was. Uit andere gegevens bleek voorts wel, dat althans in de jaren dertig de rentestand in Nederland laag was, 3 procent, en iets hoger, 3,2 procent in Ned. Indië (cf. J. TINBERGEN, ed., Shaping the World Economy. Suggestions for an International Economie Policy, New York, 1962, Appendix V, 3, 259-260). Ook was de rentestand in Engeland toen iets hoger, in Duitsland zelfs soms aanmerkelijk (tot 6 procent). Maar hieruit conclusies te trekken in een door mij gestelde zin, lijkt ongeoorloofd. En toch geeft men zulk een in het geheugen vastgeroest begrip (of wanbegrip) maar node prijs! 
Tot zover de wel uiterst summiere balans voor het 'moederland'. Voor de koloniale bevolkingen is die nog moeilijker op te maken. In het algemeen zal de materiële positie in de meeste landen wel door de Europese activiteiten gestegen zijn - al is de eenzijdige roofbouw van Leopold II (overigens geinspireerd door het Nederlandse cultuurstelsel! ${ }^{41}$ ) geen uitzondering. Men moet daaruit echter niet al te vlotweg concluderen, zoals Lord Hailey $\operatorname{doet}^{42}$, dat wanneer de Europese exploitatie maar zekere garanties ten bate van de inheemse bevolking in acht neemt, de leuze kan gelden: hoe méér Europese exploitatie hoe beter. Die garanties zijn namelijk geheel afgesteld op de vormen van de vrije markteconomie en verder beperkt tot de afwezigheid van materiële en andere overmachtsuitoefening. Een dergelijke, typisch Westers-liberale waarborg die niet kan voorkomen dat ook op de Westerse markt allerlei verkapte machtselementen de positie van de werknemer als de zwakkere partij ongunstig beïnvloeden, is in de koloniale sfeer ongetwijfeld nog veel meer fictief.

Het is opmerkelijk dat noch Hailey, noch Gann en Duignan, die in hun Burden of Empire een uitgesproken rehabilitatie van het koloniaal bestel beogen, gewag maken van drie bekende omstandigheden of factoren, die de zegeningen van de kolonisatie nadelig beïnvloeden of zelfs geheel tenietdoen; ik bedoel:

1. de opheffing van de materiële vooruitgang door de begeleidende bevolkingsexplosie;

2. het verschijnsel van de 'rising expectations', die de uit het Westen overgebrachte dynamiek onvermijdelijk meebrengt maar waarvoor de voorwaarden niet gegeven zijn noch geleverd worden;

3. de toeëigening door de Westerse exploitanten van het leeuwendeel van de baten in het heden èn voor de toekomst, onder andere omdat de opgebrachte dividenden etc. en de daaruit mogelijke kapitaalsaccumulatie voor het merendeel niet in de economie van de koloniale, maar van de imperiale volken zijn opgegaan en die hebben bevrucht.

Gann en Duignan weigeren in hun apologie van het Westen, die stellig ook allerlei scheve voorstellingen naar de andere kant rechtzet, zich met het probleem van een eventuele 'psychologische exploitatie' van de Afrikaanse volken in te laten, omdat die niet meetbaar zou zijn. Hetgeen hen er niet van weerhoudt, de opvattingen van Mannoni en Frantz Fanon op dit gebied nadrukkelijk af te wijzen ${ }^{43}$. Zij menen wel een maatstaf te hebben vooreen vooruitgang in algemeen-culturele zin. Die zou dan te vinden zijn 'in het aantal keuzen, dat de deelgenoten aan een cultuur kunnen doen en inhun vermogen's mensen capaciteiten tot ontwikkeling te brengen'. Een op het eerste gezicht niet onredelijk criterium. Maar als zij dan de afstammeling van een Ma-

41. STENGERS, 'Congo Free State', 282-283.

42. W. M. HAILEY, The Future of Colonial Peoples (Princeton, 1944) 22.

43. Cf. GANN en DUIGNAN, Burden of Empire, vi-viii. 
tabelekrijger in vergelijking met zijn voorvader gelukkig prijzen, omdat deze nu de kans heeft op een bestaan als onderwijzer, koopman, bus-eigenaar, beambte, boer of kleermaker, vraagt men zich wel af, of hier werkelijk van een niet alleen relatieve, maar volgens de schrijvers zelfs absolute vooruitgang sprake is. Misschien is het een wat provinciale of Rhodesische interpretatie van de Westerse cultuur, die de schrijvers hierbij parten speelt ${ }^{44}$.

Wat men wel kan poneren is, dat het imperialisme langs dialektische weg de tegenkrachten tegen zichzelf in het leven heeft geroepen en daardoor mede de emancipatie van de Afrikaanse, Aziatische en andere koloniale volken in de hand heeft gewerkt. Maar die emancipatie is dan veelal op een zo laag niveau of op zo beperkte schaal voltrokken, terwijl de materiële, institutionele en geestelijke afstand tot de Westerse landen niet verminderd is, dat deze kloof voor de wereld van heden, na de dekolonisatie, de grootste uitdaging vormt waarop zowel een negatieve als een positieve 'respons' mogelijk is.

Schrijvers als Herbert Lüthy en Gollwitzer kennen het moderne imperialisme als verdienste de historische voltrekking van de eenwording der wereld toe ${ }^{45}$. Deze eenwording voltrok zich evenwel via een proces van felle rivaliteiten en heftige tegenstellingen. $\mathrm{Zij}$ is in haar geladenheid aan conflicten niet los te denken van de grote botsingen in deze moderne wereld, die een zware hypotheek aan machtslust, rancune en gewelddadige agressie hebben achtergelaten. Zowel in zijn Westers-kapitalistische gedaante als in zijn ideologisch antithetische, maar praktisch analoge communistische, zogenaamd 'anti-imperialistische' verschijningsvormen heeft het imperialisme de hele wereld, de ex-koloniale incluis, geïnfecteerd met het virus van een ongeremd streven naar macht en profijt, naar materiële en geestelijke superioriteit ten koste van anderen. De 'disparity of power' werkt nog immer: men zie slechts naar de relaties tussen Noord- en Zuid-Amerika, naar de spanningen en conflicten in Oost-Europa en het Nabije Oosten en in Zuid-Oost-Azië. Hier heeft het virus zijn grote kansen. Het blijft geboden, het achter alle verhullingen, ideologische of andere, op te sporen en aan de kaak te stellen. Daarom blijft het tijdvak van het Moderne Imperialisme, toen dit virus een paroxysme aan vitaliteit en verspreiding beleefde, een historisch probleem van grote actualiteit.

Om zich van dit imperialistische virus te bevrijden zullen de volken, ex-imperiale zowel als ex-koloniale, zich van hun erfelijke belastheid bewust moeten maken. Dat

44. L. H. Gann heeft veel in Rhodesië en Zambia gewerkt, o.a. in de 'nationale archieven' van Rhodesië en Nyasaland. GANN EN DÜIGNAN schreven ook een speciaal werk over de White Settlers in Tropical Africa (Harmondsworth, 1962). Zij zijn thans werkzaam aan de Hoover Institution on War, Revolution and Peace in Stanford, die ook hun Burden of Empire uitgaf.

45. H. LÜTHY, 'Colonization and the Making of Mankind', JEH, XXI, iv (1961) 483-495; gedeeltelijk overgenomen in G. H. NADEL EN P. CURTIS, Imperialism and Colonialism (Main Themes in European History, New York, 1964) 26-37. Gollwitzer sluit zich in zijn conclusie nauw bij Lüthy aan. Zie: GOLLWITZER, Imperialism, 194. 
B. W. SCHAPER

is slechts mogelijk door de analyse van hun imperiale en koloniale verleden. Zulk een analyse behoort tot de functies van de geschiedenis. Ook voor het Nederlandse volk dat zowel in pragmatische als dogmatische zin tot een zekere naïveteit geneigd is, zal zulk een historisch zelfonderzoek dat bepaald niet in zelfbeschuldigingen of masochisme behoeft te ontaarden, een bevrijdende werking kunnen hebben.

Ik meen dan ook dat het historisch congres dat aan de Nederlandse verschijningsvormen van het Imperialisme gewijd is en waarvoor deze algemene inleiding als een soort praeludium moet dienen, bewijst dat de Nederlandse historici zich van hun taak en verantwoordelijkheid in de wereld van heden ten volle rekenschap geven. 


\title{
De Indonesische samenleving aan de vooravond van de imperialistische expansie: configuraties en stromingen
}

\author{
W. F. WERTHEIM
}

Mijn taak is, te pogen enkele hoofdlijnen van ontwikkeling aan te geven in de periode, die voorafgaat aan de eigenlijke imperialistische expansie. Deze periode wordt dus begrensd door de openstelling van het Suez-kanaal en door het Sumatra-tractaat. Tevens wordt zij begrensd door de agrarische wetgeving van de jaren zeventig, die de uitgifte aan particulieren van erfpachtsgronden voor de duur van 75 jaar mogelijk maakte.

In zekere zin kan men ook de voorafgaande periode al een van 'imperialistische' expansie noemen. Als een belangrijk verschil zie ik, dat in die tijd - met name onder het cultuurstelsel - de koloniale exploitatie in Indonesië meer gericht was op de beschikking over arbeid dan over grond. Pas met de opbloei van de tabakscultuur in Deli begint een zeer extensieve exploitatie van de bodem, onder een rotatiesysteem waarbij uitgestrekte gebieden wel ter beschikking komen te staan van westerlingen, maar om cultuurtechnische redenen braak blijven liggen.

Het verschil met de voorafgaande periode is er dus niet alleen een van particuliere versus overheidsexploitatie. Ook het exploitatie-object wordt anders. Vooral de suikercultuur op Java was tijdens het cultuurstelsel sterk gericht op een intensief benutten van de inheemse arbeid. Wat deze suikercultuur betreft zijn de veranderingen na 1870 veel minder ingrijpend. Op Java wordt de nieuwe periode alweer gekenmerkt door de uitgifte van uitgestrekte gebieden, met name in bergachtige streken, in erfpacht voor de verbouw van overjarige gewassen.

De zware druk van cultuurdiensten had al tijdens het cultuurstelsel de Indonesische dorpsgemeenschap ernstig aangetast. Deze druk werkte grotendeels nivellerend. Om aan de eisen van overheidswege tegemoet te komen moest in vele streken het adatrechtelijk onderscheid tussen kerndorpers, die volledig dienstplichtig waren, en andere dorpelingen die slechts een deel van de rechten genoten maar ook maar een deel van de lasten droegen, worden losgelaten. Het dorpshoofd werd boven de dorpsgemeenschap uitgetild én tot werktuig van het koloniaal gezag gemaakt - maar daarmee kon hij ook economisch, met zijn familie, boven de gewone tanis uitstijgen. Maar voor de brede massa van dorpelingen was er een tendentie naar grotere gelijkschakeling in economisch niveau.

Bepaalde sociale processen komen al in deze periode op gang. Zo bij voorbeeld het door Clifford Geertz beschreven involutieproces, het steeds streotieper en ingewik- 